\title{
Sensitivity of Erwinia amylovora in Illinois Apple Orchards to Streptomycin, Oxytetracyline, Kasugamycin, and Copper
}

\author{
A. G. Jurgens and M. Babadoost, Department of Crop Sciences, University of Illinois, Urbana 61801
}

\begin{abstract}
Jurgens, A. G., and Babadoost, M. 2013. Sensitivity of Erwinia amylovora in Illinois apple orchards to streptomycin, oxytetracyline, kasugamycin, and copper. Plant Dis. 97:1484-1490.

In 2008 and 2009, severe fire blight (Erwinia amylovora) occurred in Illinois apple orchards, leading to speculation that streptomycinresistant strains of $E$. amylovora might be present in some orchards. Statewide surveys were conducted in 2010, 2011, and 2012, and 117, 129 , and 170, E. amylovora isolates were collected, respectively, from 20 counties. None of the 416 E. amylovora isolates tested were resistant to streptomycin (Agri-Mycin 17WP) at $50 \mathrm{mg} / \mathrm{liter}$. Seven nonE. amylovora bacterial isolates were collected from E. amylovorainfected shoots that contained both a strA-strB streptomycin resistance gene and IS1133 on transposon Tn5393, which could be a potential source of streptomycin resistance for E. amylovora in Illinois in the future. Colony development of all $84 \mathrm{E}$. amylovora isolates tested was inhibited on Luria-Bertani medium amended with oxytetracycline at 50

$\mathrm{mg} / \mathrm{liter}$ and kasugamycin (Kasumin $2 \mathrm{~L}$ ) at $100 \mathrm{mg} / \mathrm{liter}$. Similarly, colony development of the $84 \mathrm{E}$. amylovora isolates was inhibited on casitone-yeast extract medium amended with copper sulfate at 0.16 mM. In 2011 and 2012, field trials were conducted to evaluate the efficacy of oxytetracycline (Mycoshield 17WP), kasugamycin (Kasumin 2L and ARY-4016-06), copper hydroxide (Kocide-3000 41.6DF), Bacillus subtilis (Serenade Max, QST713), and Pseudomonas fluorescens (Blight Ban A506) for management of fire blight in an apple orchard. Only kasugamycin (Kasumin 2L and ARY-4016-06) reduced blossom infection significantly. There was a significant interaction of kasugamycin (Kasumin 2L) with prohexadione calcium (Apogee 27.5DF) in reducing shoot blight incidence in the field in 2012.
\end{abstract}

Fire blight disease, caused by the bacterium Erwinia amylovora (Burrill) Winslow et al., is a serious disease of pome fruit, especially apple (Malus $\times$ domestica Borkh.) and pear (Pyrus spp.), worldwide (3). Yield losses to fire blight and control costs of the disease in the United States are estimated at $\$ 100$ million per year (17).

E. amylovora overwinters at the edges of cankers of infected trees. In spring, when temperatures exceed $18.3^{\circ} \mathrm{C}$, the bacteria rapidly multiply and become the primary inoculum $(3,6)$. Rain splash, wind, and insects spread the bacteria onto the flowers, leaves, and shoots. Infection is initiated as the bacteria enter through natural openings and wounds, multiply, invade, and kill host tissue (3).

Control of fire blight requires year-round comprehensive management practices, including pruning, early-spring copper applications, and bactericide applications during bloom and following storm trauma to prevent the bacterium from entering through the nectarthodes or wounds and infecting the host tissue (3). Since the 1950s, streptomycin has been the primary bactericide used for fire blight control and has been highly effective. However, in 1971, the first detection of streptomycin-resistant (SmR) E. amylovora occurred in California (16). Subsequently, SmR E. amylovora was reported from the western United States, Michigan, Canada, and Israel, and has been isolated in New York $(2,9,11,12,18,20)$. During 2003 to 2009, in Michigan, two genotypes of SmR isolates were collected: (i) $s t r A-s t r B$ genes, encoding phosphotransferase enzymes modifying streptomycin to a nonbactericidal form, and (ii) a point mutation of ribosomal S12 protein, RspL (12). McGhee et al. (12) reported that $\operatorname{str} A-\operatorname{str} B$ genes harbored on transposon Tn5393 were present in $98.7 \%$ of SmR isolates in Michigan, whereas RspL mutations dominated other regions with streptomycin resistance. This indicated that, in Michigan, SmR likely moved from SmR

Corresponding author: M. Babadoost, E-mail: babadoos@illinois.edu

Accepted for publication 30 May 2013.

http://dx.doi.org/10.1094/PDIS-02-13-0209-RE

(C) 2013 The American Phytopathological Society non-target orchard bacteria via horizontal gene transfer on Tn5393 into E. amylovora (12).

Currently, registered streptomycin alternatives are considered less effective, unless SmR populations are present (23). However, recent laboratory and field data suggest that the antibiotic kasugamycin (Kasumin 2L; Arysta Life Science) is a suitable streptomycin alternative $(1,13)$. Kasugamycin is an antibiotic in the same class of streptomycin but has a different mode of action $(7,13)$.

In 2008 and 2009, fire blight infection was widespread and severe throughout Illinois, particularly in western parts of the state. Some growers hypothesized that $\mathrm{SmR}$ strains of E. amylovora might be present in Illinois. The objective of this study was to evaluate sensitivity of E. amylovora in Illinois to streptomycin, streptomycin alternatives, and copper.

\section{Materials and Methods}

Field survey and sample collection. Incidence and severity of blossom blight and shoot blight caused by E. amylovora were assessed in 24, 35, and 39 apple orchards in Illinois in 2010, 2011, and 2012, respectively. Surveyed apple orchards were located in 24 counties, including Boone, DeKalb, Kane, McHenry, and Winnebago in northern; Calhoun, Champaign, Jersey, Macoupin, Marshall, Peoria, Piatt, Putnam, Sangamon, and Woodford in central; and Clinton, Jackson, Jefferson, Madison, Marion, Pope, Randolph, St. Clair, and Union in southern Illinois (Fig. 1).

In each orchard, 50 asymptomatic flowers (2 flowers/tree) and 20 symptomatic shoots ( 1 shoot/tree) were collected for isolation of the bacterium (E. amylovora). No symptomatic flowers were observed. Each infected shoot was cut $20 \mathrm{~cm}$ below the visible necrotic tissue and pruners were dipped in $95 \%$ ethanol between cuts. Collected flowers and shoots were placed in plastic bags, kept on ice during transport, and stored at $4^{\circ} \mathrm{C}$ in the laboratory within $12 \mathrm{~h}$ of collection. In 2010, shoots were collected on 3 June and 22 July. In 2011, flowers were collected on 10 April and 16 May and shoots were collected on 7 June and 22 June. In 2012, flowers were collected on 23 March and 9 April and shoots were collected on 25 May and 8 June.

Isolation, purification, and maintenance of $E$. amylovora. Luria-Bertani (LB) medium was used for isolation and maintenance 
of E. amylovora (12). LB medium was amended with cycloheximide $(50 \mathrm{mg} / \mathrm{liter})$ to make $\mathrm{LBch}$. LBch was amended with 50 $\mathrm{mg} / \mathrm{liter}$ of streptomycin (Agri-Mycin 17WP; Nufarm Americas Inc.) to make LBcham.

All collected samples were processed within $36 \mathrm{~h}$ of collection. Five flowers were placed in a mesh bag (Agdia, Inc.) with $5 \mathrm{ml}$ of sterilized $0.5 \times$ phosphate-buffered saline (PBS) buffer, on ice. Flower tissue was macerated for approximately $20 \mathrm{~s}$ or until tissue was well ground using a tissue homogenizer (Agdia, Inc.) attached to a drill press. For isolation of the bacterium from shoots, a 10- to 15-mm piece of shoot tissue was cut immediately below the visible necrotic lesion and bark was removed using sterile scalpel and tweezers. The shoot tissues were macerated as described for flowers. Then, underneath a sterile hood, extract from ground tissue was diluted (3:1) in sterilized $0.5 \times$ PBS buffer. Using a bacterial loop, the suspension was streaked to develop single colonies on $\mathrm{LBch}$ and LBcham. The cultures were incubated at $27^{\circ} \mathrm{C}$ for 48 h. White colonies characteristic of E. amylovora on LBch and all white colonies growing on LBcham were subcultured on LB; then, each colony was transferred to a cryogenic vial containing $15 \%$ glycerol. The vials were stored at -20 and $-80^{\circ} \mathrm{C}$ for further studies.

PCR identification of E. amylovora. The identity of each $E$. amylovora isolate was confirmed by using a polymerase chain reaction (PCR). The PCR was conducted using primers AJ75 (5' CGC ATT CAC GGC TTC GCA GAT 3') and AJ76 (5' AAC CGC CAG GAT AGT CGC ATA 3') targeting ubiquitous plasmid pEA29 in $E$. amylovora (15). Using a sterile pipette tip, a colony was suspended in $100 \mu \mathrm{l}$ of sterilized distilled water (SDW). Then, $0.5 \mu \mathrm{l}$ of the bacterial suspension was added to $10 \mu \mathrm{l}$ of DNA-free water, $1 \mu \mathrm{l}$ of each primer AJ75 and AJ76 (10 pmol/ $\mu \mathrm{l})$, and $12.5 \mu \mathrm{l}$ of Gotag Green Master Mix 2x (Promega Corporation) for a final reaction mixture volume of $25 \mu \mathrm{l}$. Cycling conditions for PCR (Model PCT-200; MJ Research Inc.) included initial denaturation at $94^{\circ} \mathrm{C}$ for $5 \mathrm{~min} ; 37$ cycles of denaturation for $1 \mathrm{~min}$, annealing at $52^{\circ} \mathrm{C}$ for $2 \mathrm{~min}$, and extension at $72^{\circ} \mathrm{C}$ for $2 \mathrm{~min}$; followed by 15 min of final extension at $72^{\circ} \mathrm{C}$, and was kept at $4^{\circ} \mathrm{C}$ until electrophoresis. The PCR product was run on $1 \%$ agarose gel containing ethidium bromide at $100 \mathrm{~V}$ for $60 \mathrm{~min}$, and photographed under UV light. The bands were compared with a known streptomycinsensitive E. amylovora isolate, MK1, and a streptomycin-resistant E. amylovora isolate, Ea88, supplied by George Sundin (Michigan State University). The process was repeated at least once for each isolate.

Virulence of $\boldsymbol{E}$. amylovora isolates. An immature pear fruit assay (4) was used to determine virulence of $48 \mathrm{E}$. amylovora isolates from Illinois. Immature 'Seckel' pear fruit were surface disinfested in $75 \%$ ethanol, rinsed in SDW, and dried on a sterile lab bench. Using a sterile pipette, a $15-\mu \mathrm{l}$ suspension $\left(10^{7} \mathrm{CFU} / \mathrm{ml}\right)$ of each isolate was inoculated into each pear fruit (approximately 2 $\mathrm{mm}$ deep). E. amylovora isolate MK1 and SDW were used as positive and negative controls, respectively. Inoculated and control pears were incubated in a moist chamber at $27^{\circ} \mathrm{C}$ in darkness. Diameters of necrotic lesions were measured perpendicularly 4 and 7 days post inoculation. Each virulence test had five replications (fruit) and the experiment was repeated once. The virulence tests were complimented with a tobacco hypersensitivity assay to determine the presence of type III effectors, as described by Kado (8).

Screening $E$. amylovora isolates for streptomycin sensitivity. In all, 416 E. amylovora isolates were cultured on LB medium and LB medium amended with streptomycin at $50 \mathrm{mg} /$ liter (Agri-Mycin 17WP). The streptomycin-sensitive isolate MK1 and streptomycin-resistant isolate Ea88 were used as negative and positive controls, respectively. Colony development was recorded after 24 and $48 \mathrm{~h}$. Each isolate was evaluated in two experiments, with three replications per experiment.

Of 416 E. amylovora isolates, 133 were further tested for streptomycin sensitivity by zone of inhibition. Each isolate was grown on LB medium for $48 \mathrm{~h}$. Colonies were washed in SDW and the bacterial suspensions were adjusted to $10^{7} \mathrm{CFU} / \mathrm{ml}$ using a spectrophotometer (Smart Spec 3000; Bio-Rad). Using a sterilized bent glass rod, a $50-\mu l$ bacterial suspension was spread onto LB medium. A 12-mm filter disc was soaked in a $100 \mathrm{mg} / \mathrm{liter}$ solution of streptomycin (Agri-Mycin 17WP), briefly dried, and placed onto the agar surface, as described by Loper et al. (11) and Russo et al. (18). The streptomycin-susceptible isolate MK1 and streptomycin-resistant isolate Ea88 were used as positive and negative controls, respectively. Clear zones of inhibition were measured at 24 and $48 \mathrm{~h}$. The width of zone $(\geq 1 \mathrm{~mm})$ with no bacterial colony was considered a measure of sensitivity of E. amylovora to streptomycin. Each isolate was tested twice, each test had three replications, and each replication had four filter discs.

In addition, 10 of the 416 E. amylovora isolates were compared for bacterial multiplication in LB broth (Miller; Arcos Organics) amended with streptomycin (Agri-Mycin 17WP) at 0, 0.5, 1, 2, 3, 4 , and $5 \mathrm{mg} / \mathrm{liter}$ and in nutrient broth (BD, Sparks, MD) amended with streptomycin (Agri-Mycin 17WP) at 0, 0.25, 0.5, and 1 $\mathrm{mg} / \mathrm{liter}$. The tests were conducted using sterile 24-well plates (351147; BD Falcon). From each bacterial suspension $\left(10^{8}\right.$ $\mathrm{CFU} / \mathrm{ml}$ ), $20 \mu \mathrm{l}$ was added to $2 \mathrm{ml}$ of broth in each well and incubated on a shaker at $28^{\circ} \mathrm{C}$ for $18 \mathrm{~h}$. Bacterial cell density was assessed using a spectrophotometer at an optical density at $600 \mathrm{~nm}$ $\left(\mathrm{OD}_{600}\right)$. The bacterial cell densities from the streptomycinamended cultures were compared with unamended cultures and
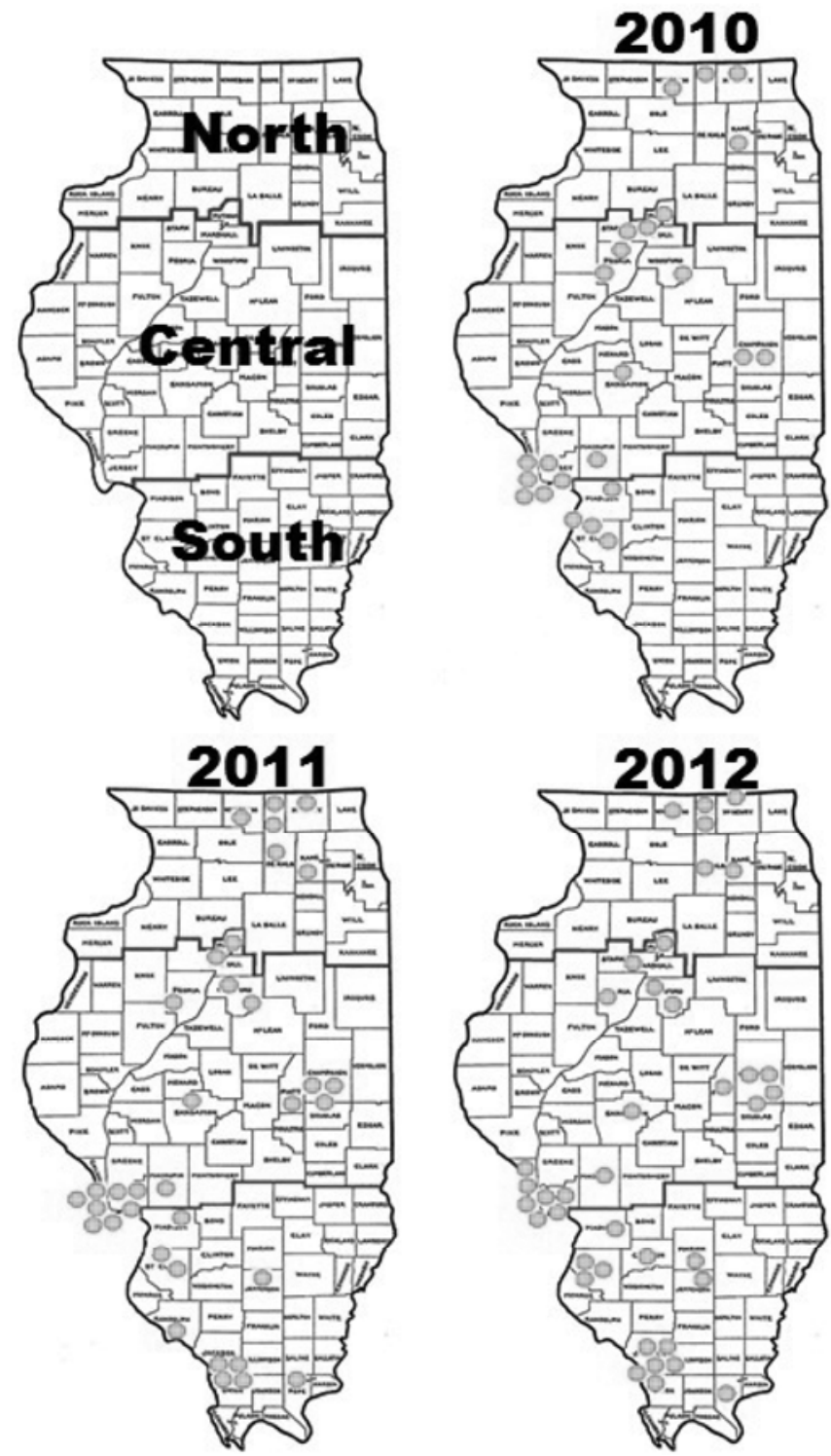

Fig. 1. Circles show locations of Illinois apple orchards surveyed for streptomycinresistant Erwinia amylovora during 2010 to 1012. 
expressed as a percentage. Each isolate was tested twice with four replications.

Non-E. amylovora bacteria in Illinois orchards. While testing blossom and shoot samples for the presence of E. amylovora, 119 non-E. amylovora isolates were also collected that developed colonies with streptomycin at $50 \mathrm{mg} /$ liter. All 119 non-E. amylovora isolates were screened for the presence of IS1133 region (associated with Tn5393) using primer set IS1133-F ('GCG TGA TGC AGT TCG CAT AGC') and IS1133-R ('CAT ACG CGG CCT ACC ATA GCT') (12). The IS1133 region of nine isolates was sequenced using primer IS1133-F, except the cycling parameters were modified as described below.

These nine non-E. amylovora isolates were also screened with primers strab01-F ('TGG TGT CCC GCA ATG CCG TC') and strab01-R ('CCC GGA TCG GGA GAA GGG CA') to amplify a portion of $s t r \mathrm{~B}$ region on $\mathrm{Tn} 5393$. PCR cycling conditions included initial denaturing for $4 \mathrm{~min}$ at $94^{\circ} \mathrm{C} ; 40$ cycles of denaturation at $94^{\circ} \mathrm{C}$ for $30 \mathrm{~s}$, annealing at $55^{\circ} \mathrm{C}$ (IS1133 primer set) or $60^{\circ} \mathrm{C}$ (strab01 primer set) for $30 \mathrm{~s}$, and extension at $72^{\circ} \mathrm{C}$ for 2.5 min; followed by a final extension at $72^{\circ} \mathrm{C}$ for $7 \mathrm{~min}$. The PCR product was run in $1 \%$ agarose gel containing ethidium bromide at $100 \mathrm{~V}$ for $60 \mathrm{~min}$, and photographed under UV light. The bands and sequences were compared with results produced by E. amylovora isolates MI 5-1 and W4 that are known to contain Tn5393 (12). The process was repeated twice for each isolate.

The PCR test was performed to amplify the 16S rRNA genes from the extracted DNA using the primers 27F (5' AGA GTT TGA TCM GGC TCA G $3^{\prime}$ ) and 1492R (5' GGT TAC CTT GTT ACG ACT T $3^{\prime}$ ), as described by Lane (10). PCR products were purified with the Wizard SV gel and PCR Clean-Up system (Promega Corporation). Purified 16S rRNAs were single-end sequenced from $27 \mathrm{~F}$ at the University of Illinois Core DNA Sequencing Facility. Edited sequences were compared using the BLASTn database (http://www.ncbi.nlm.nih.gov).

Oxytetracycline and kasugamycin sensitivity. Of the $416 E$. amylovora isolates, 84 were selected for in vitro evaluation of antibiotics. LB medium ( $\mathrm{pH} 7$ ) was amended with oxytetracycline (Mycoshield 17WP; NuFarm Americas Inc.) at 0, 50, 100, and 200 $\mathrm{mg} /$ liter. Also, two formulations of kasugamycin (Kasumin $2 \mathrm{~L}$ and ARY-4016-06; Arysta Life Science) were evaluated at 0, 25, 50, and $100 \mathrm{mg} / \mathrm{liter}$ in LB medium with bacterial suspensions streaked onto the agar surface. All experiments included unamended LB medium for controls. Colony development of $E$. amylovora was assessed after 24 and $48 \mathrm{~h}$.

Ten E. amylovora isolates were further compared in nutrient broth (pH 7) amended with Kasumin 2L and ARY-4016-06 (kasugamycin at $0,3,5$, and $10 \mathrm{mg} / \mathrm{liter}$ ) for bacterial multiplication. This test was conducted as described previously for the streptomycin test. The test was conducted using sterile 24 -well plates, with $20 \mu \mathrm{l}$ from each bacterial suspension $\left(10^{8} \mathrm{CFU} / \mathrm{ml}\right)$ added to $2 \mathrm{ml}$ of amended nutrient broth in each well and incubated on a shaker at $28^{\circ} \mathrm{C}$ for $18 \mathrm{~h}$. Bacterial cell density was assessed using a spectrophotometer at $\mathrm{OD}_{600}$.

Copper sensitivity. The same 84 E. amylovora isolates were also evaluated for their sensitivity to copper sulfate using casitoneyeast extract (CYE) medium (1.7 $\mathrm{g}$ of casitone, $0.35 \mathrm{~g}$ of yeast extract, $2 \mathrm{~g}$ of glucose, and $15 \mathrm{~g}$ of agar in 1,000 $\mathrm{ml}$ of deionized water), as reported by Loper et al. (11). CYE medium was amended with $0.08,0.16$, and $1.1 \mathrm{mM}$ copper sulfate (Cuprofix Ultra 40DF; United Phosphorus). A 10- $\mu$ l aliquot of bacterial suspension from each isolate was spotted onto the agar surface in each 110-mm-diameter petri plate. All experiments included unamended agar plates for controls. Each isolate was tested twice, with three replications (plates) per test. Colony development was assessed after 48 and $72 \mathrm{~h}$.

Of the 84 E. amylovora isolates, 11 were further evaluated for their sensitivity to various copper formulations with metallic copper at 0 and $14 \mathrm{mg} / \mathrm{liter}$. CYE medium was amended with copper sulfate (Cuprofix Ultra 40DF), copper hydroxide (Kocide 3000 40.1DF; Dupont); cuprous oxide (Nordox 75 WG; Nordox Indus- tries AS), and a mixture of copper hydroxide and copper oxychloride (Badge X2 45DF; Isagro USA). Colony development was assessed after 48 and $72 \mathrm{~h}$.

Field experiments. Field experiments were conducted in 2011 and 2012 to evaluate potential streptomycin alternative compounds for management of fire blight. The experiments were conducted on a 16-year-old block of 'Jonathan' apple trees at the University of Illinois Fruit Research Farm, Urbana. Inoculum of E. amylovora was prepared from 48-h-old colonies of the isolate (2A) that had been collected from the same orchard. Bacterial suspensions in $0.5 \times \mathrm{PBS}$ buffer at $10^{8} \mathrm{CFU} / \mathrm{ml}$ (in 2011) and $5 \times 10^{6} \mathrm{CFU} / \mathrm{ml}$ (in 2012) were used. The bacterial suspension was transported on ice and applied when a MARYBLYT disease forecasting logger (Watchdog 400; Spectrum Technologies) indicated high risk of fire blight infection. All treatments and inoculations were applied using a gas-powered backpack mist sprayer (SR400; Stihl) at 1,400 liters/ha. Data were collected on four sides of each tree from the upper, middle, and lower canopy. In total, 120 flower clusters and 120 shoots were examined on each tree when it was possible. In 2012, the number of flower clusters per tree ranged from 6 to 120 (mean 70 clusters) per tree.

The 2011 experiment was performed in a randomized complete block design with eight treatments, and each treatment had two application times of $24 \mathrm{~h}$ pre- and $24 \mathrm{~h}$ post inoculation. Each treatment had three replications for each application time, with 1 tree for each replication (48 trees in the experiment). The treatments included (i) an uninoculated control, (ii) an inoculated control, (iii) streptomycin (Agri-Mycin 17WP) at $100 \mathrm{mg} / \mathrm{liter}$, (iv) oxytetracycline (Mycoshield) at $200 \mathrm{mg} / \mathrm{liter}$, (v) kasugamycin (Kasumin 2L) at $100 \mathrm{mg} /$ liter, (vi) kasugamycin (ARY-4016-06) at $100 \mathrm{mg} / \mathrm{liter}$, (vii) Pseudomonas fluorescens A506 (BlightBan A506) at $369 \mathrm{mg} / \mathrm{liter}$, and (viii) Bacillus subtillus QST713 (Serenade Max) at $525 \mathrm{mg} /$ liter.

Cuprofix Ultra 40D $(7.8 \mathrm{~kg} / \mathrm{ha})$ and dormant oil were applied to all trees on 31 March 2011. Growth development stages of apple trees were full pink (18 April), $1 \%$ bloom (20 April), 40 to $60 \%$ bloom (25 April), and petal fall (11 May). The trees were inoculated with the pathogen twice (on 26 April and 8 May) to ensure that adequate inoculum was present. Pre-inoculation treatments (treatments iii to viii) were applied on 25 April and 7 May and post-inoculation treatments (treatments iii to viii) were applied on 27 April and 9 May. All plots received an additional spray of the respective test product on 29 April, a timing that was independent of the pre- and post-inoculation timings sprays. As a result, all test trees received a total of three fire blight control sprays during bloom. Blossom infection was evaluated on 12 May and 23 May and shoot infection was evaluated on 10 June, 30 June, and 27 July.

The 2012 experiment was a split-plot in a randomized complete block design with 11 main plots (antibiotics and biocontrol agents), each with two subplots of with or without growth regulator prohexadione calcium (Apogee 27.5DF; BASF Corporation) at 1,200 $\mathrm{mg} / \mathrm{liter}$. Each treatment had four replications (trees). The main plot treatments included (i) inoculated control, (ii) copper hydroxide (Kocide 3000) at $240 \mathrm{mg} / \mathrm{liter}+$ mancozeb (Dithane 75DF, Dow AgroSciences LLC) at 2,700 mg/liter, (iii) streptomycin (Agri-Mycin 17WP) at $100 \mathrm{mg} / \mathrm{liter}$, (iv) oxytetracycline (Mycoshield) at $200 \mathrm{mg} / \mathrm{liter}$ (v) oxytetracycline (Mycoshield) at 200 mg/liter+ copper hydroxide (Kocide 3000) at $240 \mathrm{mg} / \mathrm{liter}$, (vi) kasugamycin (Kasumin 2L) at $100 \mathrm{mg} /$ liter, (vii) kasugamycin (ARY-4016-06) at $100 \mathrm{mg} / \mathrm{liter}$, (viii) P. fluorescens A506 (BlightBan A506 71) at $369 \mathrm{mg} / \mathrm{liter}$, (ix) B. subtillus (Serenade Max QST713) at $525 \mathrm{mg} / \mathrm{liter}$, (x) kasugamycin (Kasumin 2L) at 100 $\mathrm{mg} /$ liter, and (xi) streptomycin (Agrimycin 17WP) at $100 \mathrm{mg} / \mathrm{liter}$. Treatments ii to vii were applied $24 \mathrm{~h}$ pre- and $24 \mathrm{~h}$ post-inoculation; treatments viii and ix were applied $24 \mathrm{~h}$ pre-inoculation only; and treatments $\mathrm{x}$ and $\mathrm{xi}$ were applied $24 \mathrm{~h}$ post-inoculation only. All 11 treatment applications included a nonionic surfactant, Regulaid (Kalo, Inc.), at $1.25 \mathrm{ml} / \mathrm{liter}$.

Cuprofix Ultra 40DF (7.8 kg/ha) and dormant oil were applied to all trees on 13 March 2012. Growth development stages of apple 
trees in 2012 were full pink (23 March), 1\% bloom (26 March), 40 to $60 \%$ bloom (28 March), and petal fall (12 April). In total, Apogee $(0.925 \mathrm{~kg} / \mathrm{ha}$ of prohexadione calcium) at $3.363 \mathrm{~kg} / \mathrm{ha}$ in two sprays ( $1.68 \mathrm{~kg} / \mathrm{ha}$ in each spray) plus Regulaid ( $1.25 \mathrm{ml} / \mathrm{liter})$ were applied on 29 March (60 to $80 \%$ bloom) and 12 April (petal fall), using water at 1,400 liters/ha for each application. The trees were inoculated on 30 March and 3 April. Treatments were applied on 29 March (24 h pre-inoculation), 31 March (24 h post inoculation), 2 April (24 h pre-inoculation), and 4 April ( $24 \mathrm{~h}$ post inoculation). Additional applications of BlightBan A506 (treatment viii) and Serenade Max (treatment ix) were made on 28 March. Blossom infection was evaluated on 17 April, 24 April, and 1 May and shoot infection was evaluated on 8 May, 22 May, 5 June, and 3 July.

Data analysis. All statistical analyses were performed using SAS 9.3 (SAS Institute Inc.). Homogeneity of variances was tested using the Brown-Forsyth test and normality was observed. Percent cell multiplication data from liquid-amended media (streptomycin) were analyzed using analysis of variance (ANOVA) and means were separated by least significant difference in PROC GLM at $\alpha$ $=0.05$. All other data were analyzed using ANOVA in PROC MIXED. Percent cell multiplication data from liquid amended media (kasugamycin) were separated at $\alpha=0.05$ using macro pdmix800 (19) to indicate mean separation. Pear pathogenicity and field data were square root transformed $[\sqrt{ }(x+1 / 6)]$ before analysis. In 2012, blossom data were analyzed as a covariate to account for uneven blossom development in the orchard. Dunnett's test was used to compare blossom infection of field treatments to the inoculated control.

\section{Results}

Occurrence of fire blight in Illinois apple orchards. No blossom blight was observed during this study. E. amylovora was isolated from 2 of 214 and 1 of 221 flower samples in 2011 and 2012, respectively. Shoot blight was observed in 22 of 24, 26 of 35, and 32 of 39 of orchards in 2010, 2011, and 2012, respectively. Central Illinois had the highest and northern Illinois had the lowest incidence of shoot blight. Calhoun County in central Illinois had the highest shoot blight incidence and severity in all 3 years.

Streptomycin sensitivity of E. amylovora in Illinois. Overall, 416 E. amylovora isolates were collected from 39 individual orchards in 20 counties during 2010 and 2012. None of the $416 E$. amylovora isolates tested was streptomycin (Agri-Mycin 17WP)resistant at $50 \mathrm{mg} / \mathrm{liter}$. Differences in the streptomycin sensitivity of isolates from different counties were observed (Table 1). Isolates from Boone $(P=0.0014)$ and Champaign $(P=0.0028)$ Counties were less sensitive to streptomycin than the state mean. In contrast, isolates from Calhoun $(P=0.0143)$, Madison $(P=0.0002)$, and Union $(P=0.0056)$ Counties were more sensitive to streptomycin than the state mean.

Results from 10 individual isolates in amended LB broth supported the results of the tests on LB plates. For streptomycin at 1 $\mathrm{mg} / \mathrm{liter}$, the rates of cell multiplication of all $10 \mathrm{E}$. amylovora isolates was significantly $(P=0.05)$ reduced when compared with the streptomycin-resistant control. Calhoun isolate 6081 was the most sensitive isolate, with $0 \%$ cell multiplication for streptomycin at $3 \mathrm{mg} /$ liter, whereas the Boone isolate 7101 was the least sensitive isolate, with $16.1 \%$ cell multiplication for streptomycin at 5 $\mathrm{mg} / \mathrm{liter}$, compared with the control. In amended nutrient broth, none of the 10 tested E. amylovora isolates multiplied with streptomycin at $0.25,0.5$, or $1 \mathrm{mg} / \mathrm{liter}$.

Virulence of E. amylovora isolates. All 48 isolates of E. amylovora tested produced lesions on immature Seckel pear fruit and a hypersensitive reaction on tobacco leaves. E. amylovora was recovered from the necrotic lesions of inoculated pear fruit. Isolate 7711 from Woodford County produced the largest $(8.9 \mathrm{~mm}$ in diameter) lesions. Overall, there were no significant differences $(P=0.19)$ in diameters of the necrotic lesions produced by isolates from different counties, except isolates from St. Clair County that produced significantly $(P=0.009)$ larger necrotic lesions $(4.5 \mathrm{~mm}$ in diameter) than the state mean of lesions $(3.5 \mathrm{~mm})$ on the pear fruit.
Oxytetracycline and kasugamycin sensitivity. Colony development of all 84 E. amylovora isolates was inhibited on LB medium amended with oxytetracycline at $50 \mathrm{mg} / \mathrm{liter}$. Also, colony development of all 84 E. amylovora isolates was inhibited with kasugamycin (Kasumin 2L) at $100 \mathrm{mg} /$ liter. However, kasugamycin at $100 \mathrm{mg} / \mathrm{liter}$ in ARY-4016-06 inhibited colony development of only 35 of the 84 isolates. Kasumin 2L with kasugamycin at 50 $\mathrm{mg} / \mathrm{liter}$ inhibited colony development of 29 of 84 the isolates; whereas kasugamycin at $50 \mathrm{mg} / \mathrm{liter}$ in ARY-4016-06 inhibited colony development of only 1 of the 84 isolates.

Kasugamycin of both Kasumin 2L and ARY-4016-06 at 5 $\mathrm{mg} / \mathrm{liter}$ in nutrient broth reduced cell multiplication of all $10 \mathrm{E}$. amylovora tested (Table 2) but neither Kasumin 2L nor ARY-401606 completely inhibited cell multiplication. For kasugamycin at 10 $\mathrm{mg} / \mathrm{liter}$ in nutrient broth, however, cell multiplication of 6 of 10 and 3 of 10 was completely inhibited by Kasumin 2L and ARY4016-06, respectively.

Copper sensitivity. All 84 isolates tested developed colonies on CYE medium amended with $0.08 \mathrm{mM}$ copper sulfate. At 0.16 and $1.1 \mathrm{mM}$ copper sulfate, none of the isolates developed colonies. Also, copper sulfate, copper hydroxide, cuprous oxide, and copper hydroxide/copper oxychloride with metallic copper at $14 \mathrm{mg} / \mathrm{liter}$ inhibited colony development of all $11 \mathrm{E}$. amylovora isolates on CYE medium.

Occurrence of non-E. amylovora bacteria with Tn5393. All of the 119 non-E. amylovora isolates collected developed colonies on LB medium amended with streptomycin (Agri-Mycin 17WP) at 50 $\mathrm{mg} / \mathrm{liter}$. Seven of these isolates were confirmed to contain both IS1133 and strB (Fig. 2) on Tn5393. Three isolates (5897, 7234, and 5174) were identified as Pantoea agglomerans and one isolate (6114) as Pseudomonas graminis based on 16s rRNA sequences (450 to $600 \mathrm{bp}$ ) when compared in BLASTn.

Field experiments. In 2011, due to high inoculum density of $E$. amylovora, severe blossom blight and shoot blight developed in the inoculated trees. Only three treatments, including post-inoculation

Table 1. Streptomycin-sensitivity of Erwinia amylovora populations in Illinois apple orchards during 2010 to 2012

\begin{tabular}{lcccc}
\hline & \multicolumn{2}{c}{ Number of isolates } & & \\
\cline { 2 - 3 } County & Collected $^{\mathbf{w}}$ & Tested $^{\mathbf{x}}$ & Radius $^{(\mathbf{m m})^{\mathbf{y}}}$ & $\boldsymbol{P}$ value $^{\mathbf{z}}$ \\
\hline Boone & 14 & 7 & $2.4-$ & 0.0014 \\
Calhoun & $87+1$ & 25 & $3.5+$ & 0.0143 \\
Champaign & 32 & 9 & $2.6-$ & 0.0028 \\
Clinton & 8 & 1 & 3.0 & 0.8560 \\
Jackson & 22 & 7 & 3.1 & 0.9626 \\
Jefferson & 6 & 2 & 2.9 & 0.4742 \\
Jersey & 45 & 14 & 3.2 & 0.6900 \\
Kane & $2+1$ & 1 & 3.2 & 0.9031 \\
Macoupin & 15 & 5 & 3.2 & 0.8728 \\
Madison & 13 & 3 & $4.4+$ & 0.0002 \\
Marion & 4 & 2 & 3.1 & 0.9806 \\
Marshall & 28 & 13 & 3.1 & 0.6079 \\
Peoria & 10 & 4 & 3.2 & 0.9780 \\
Piatt & 3 & 2 & 3.8 & 0.0964 \\
Pope & 1 & $\ldots$ & $\ldots$ & $\ldots$ \\
Putnam & 15 & 5 & 2.6 & 0.0256 \\
Sangamon & 11 & 4 & 3.4 & 0.5290 \\
St. Clair & 64 & 19 & 3.3 & 0.3828 \\
Union & $24+1$ & 5 & $3.9+$ & 0.0056 \\
Woodford & 9 & 5 & 2.6 & 0.0442 \\
Total & 416 & 133 & 3.3 & $\ldots$ \\
\hline In & & & & $\ldots$ \\
\hline
\end{tabular}

${ }^{\mathrm{w}}$ In total, three isolates (indicated by +1 ), were collected from blossoms.

${ }^{x}$ Isolates were tested in three separate years and combined for analysis.

${ }^{y}$ Zone of inhibition radius. Bacterial suspension $\left(50 \mu \mathrm{l}\right.$ of $\left.10^{7} \mathrm{CFU} / \mathrm{ml}\right)$ was spread on Luria-Bertani agar; then, a $12-\mathrm{mm}$ filter disk was soaked in a solution of streptomycin (Agrimycin 17WP) at $100 \mathrm{mg} / \mathrm{liter}$, briefly dried, and placed on the agar surface. Zone of inhibition was measured after 48 h. $-=$ less sensitive to streptomycin than the state mean and $+=$ more sensitive to streptomycin than the state mean at $P=0.02$.

${ }^{\mathrm{z}}$ Data were analyzed using PROC MIXED and the LSMEAN of each county was compared with the LSMEAN of all counties combined. 
Table 2. In vitro effects of kasugamycin on Erwinia amylovora multiplication in nutrient broth ${ }^{\mathrm{y}}$

\begin{tabular}{|c|c|c|c|c|c|c|c|}
\hline \multirow{2}{*}{\multicolumn{2}{|c|}{ E. amylovora isolate }} & \multicolumn{6}{|c|}{ Bacterial cell density $(\%)^{\mathrm{z}}$} \\
\hline & & \multicolumn{3}{|c|}{ Kasugamycin (Kasumin 2L) (mg/liter) } & \multicolumn{3}{|c|}{ Kasugamycin (ARY 4016-06) (mg/liter) } \\
\hline County & Code & 3 & 5 & 10 & 3 & 5 & 10 \\
\hline Boone & 6951 & $98.9 \mathrm{bc}$ & $55.8 \mathrm{c}$ & $0.0 \mathrm{e}$ & $78.7 \mathrm{~b}-\mathrm{d}$ & $37.5 \mathrm{~cd}$ & $11.3 \mathrm{~d}$ \\
\hline Calhoun & 6081 & $100.7 \mathrm{a}-\mathrm{c}$ & $1.0 \mathrm{e}$ & $0.0 \mathrm{e}$ & $60.7 \mathrm{~b}-\mathrm{e}$ & $21.1 \mathrm{de}$ & $0.0 \mathrm{e}$ \\
\hline Calhoun & 7651 & $52.4 \mathrm{e}$ & $1.1 \mathrm{e}$ & $0.0 \mathrm{e}$ & $46.4 \mathrm{de}$ & $10.1 \mathrm{e}$ & $0.0 \mathrm{e}$ \\
\hline Champaign & 4802 & $72.0 \mathrm{~d}$ & $9.4 \mathrm{~d}$ & $0.0 \mathrm{e}$ & $38.0 \mathrm{e}$ & $6.9 \mathrm{e}$ & $0.0 \mathrm{e}$ \\
\hline Jersey & 6002 & $95.6 \mathrm{~b}$ & $67.9 \mathrm{bc}$ & $0.0 \mathrm{e}$ & $83.9 \mathrm{~b}$ & $51.6 \mathrm{bc}$ & $20.7 \mathrm{c}$ \\
\hline Sangamon & $84 d$ & $97.8 \mathrm{~b}$ & $85.9 \mathrm{a}$ & $37.7 \mathrm{a}$ & $82.0 \mathrm{~b}$ & $69.5 \mathrm{~b}$ & $59.9 \mathrm{a}$ \\
\hline St. Clair & $89 a$ & $87.6 \mathrm{c}$ & $73.4 \mathrm{~b}$ & $12.7 \mathrm{c}$ & $73.2 \mathrm{~cd}$ & $69.2 \mathrm{~b}$ & $58.5 \mathrm{a}$ \\
\hline Union & 5232 & $94.9 \mathrm{~b}$ & $70.3 \mathrm{~b}$ & $0.0 \mathrm{e}$ & $81.7 \mathrm{~b}$ & $70.8 \mathrm{~b}$ & $55.4 \mathrm{a}$ \\
\hline Woodford & 7711 & $116.6 \mathrm{a}$ & $102.1 \mathrm{a}$ & $24.0 \mathrm{~b}$ & $117.7 \mathrm{a}$ & $98.4 \mathrm{a}$ & $56.9 \mathrm{a}$ \\
\hline Woodford & $165 \mathrm{e}$ & $94.6 \mathrm{~b}$ & $73.5 \mathrm{~b}$ & $3.7 \mathrm{~d}$ & $79.4 \mathrm{bc}$ & $51.1 \mathrm{c}$ & $37.7 \mathrm{~b}$ \\
\hline Mean & $\ldots$ & 96.1 & 61.1 & 7.1 & 78.8 & 51.5 & 31.1 \\
\hline
\end{tabular}

y Nutrient broth was adjusted to $\mathrm{pH} 7$.

${ }^{\mathrm{z}}$ Bacterial cell density was measured with a spectrophotometer with an optical density at $600 \mathrm{~nm}$ at $18 \mathrm{~h}$ and expressed as a percentage of cell density in unamended control (100\%). Data were analyzed using PROC MIXED with macro pdmix800. In each column, values with a letter in common are not significantly different from each other $(P=0.05)$.

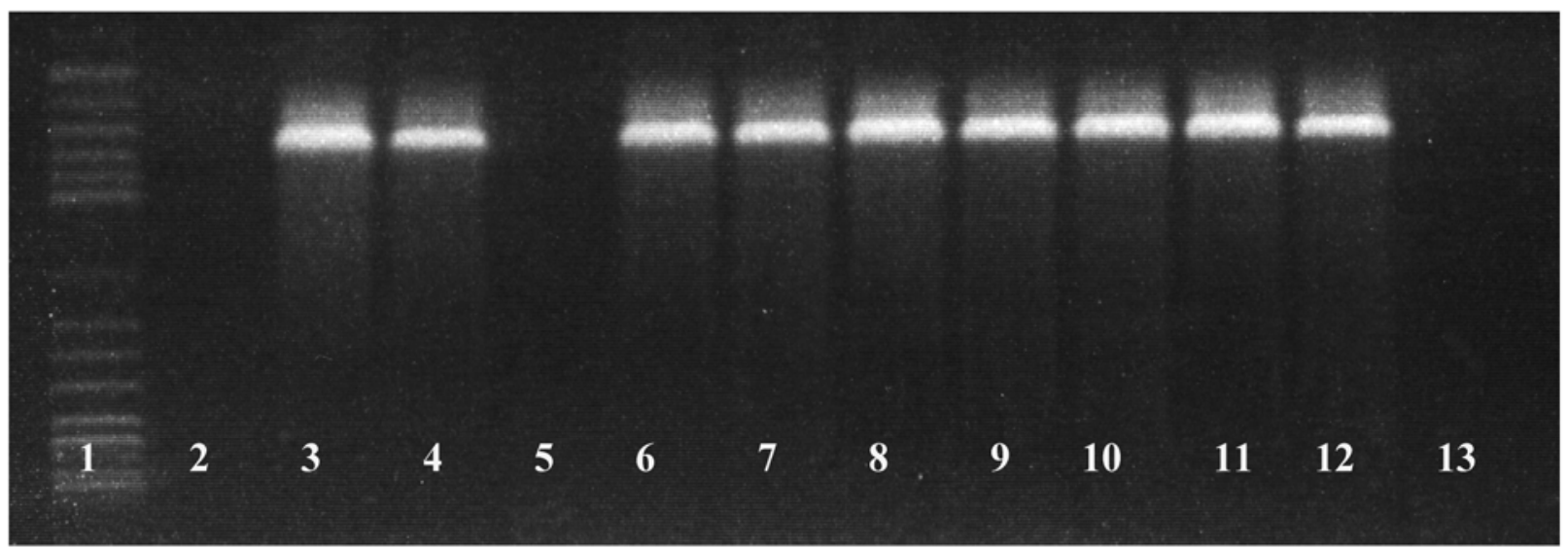

Fig. 2. Positive identification of strA-B genes in seven non-Erwinia amylovora bacterial isolates from Illinois apple orchards, using primers strab01-F ('TGG TGT CCC GCA ATG CCG TC') and strab01-R ('CCC GGA TCG GGA GAA GGG CA'). Lane 1, DNA ladder; lane 2, negative control (Mk1); lane 3, 5897 (Jersey), lane 4, 7234 (McHenry), lane 5, 5374 (no band) (Jackson), lane 6, 6114 (Calhoun), lane 7, 5814 (St. Clair), lane 8, 6004 (Jersey), lane 9, 4264 (Calhoun), lane 10, 5174 (Union); lanes 11 and 12 , positive controls (W4 and Ml 5-1, respectively); and lane 13, water control.

Agri-Mycin 17WP $(P=0.0537)$, pre-inoculation Kasumin 2L $(P=$ 0.0537), and post-inoculation ARY-4016-06 $(P=0.0234)$, significantly reduced blossom infection compared with the control.

In 2012, all treatments reduced blossom infection compared with control plots. However, significant blossom blight reduction was observed in the plots that received four antibiotic treatments, including pre- or post-inoculation Agri-Mycin 17WP $(P=0.0485)$, post-inoculation Agri-Mycin 17WP ( $P=0.0951$ ), pre- or postinoculation ARY 0416-06 $(P=0.0698)$, and pre- or post-inoculation Kasumin 2L $(P=0.1081)$ (Table 3$)$.

In 2011 and 2012, shoot infection (observed in summer) was not significantly $(P=0.10)$ reduced by bloom-time treatments to control the pathogen. In 2012, however, treatments with growth regulator Apogee reduced shoot blight significantly $(P=0.001)$ when compared with plots that did not receive Apogee (Table 4). Plots that received both Apogee and Kasumin $2 \mathrm{~L}$ (pre- and post- or postinoculation) had significantly less $(P=0.0009$ and $P=0.03$, respectively) shoot infection than Kasumin $2 \mathrm{~L}$ or Apogee alone (Table 4).

\section{Discussion}

To our knowledge, this was the first statewide survey of the occurrence of fire blight in Illinois and testing E. amylovora isolates for resistance to streptomycin. In this study, E. amylovora was isolated from only 3 of 435 flower samples tested during 2011 and 2012. None of the tested flowers showed fire blight symptoms. The results support our observations in the past 13 years that blossom blight is not common in apple orchards in Illinois. The reasons for the absence of blossom blight in Illinois are (i) streptomycin is still effective against fire blight in Illinois, (ii) almost all apple growers apply streptomycin during bloom; and (iii) temperature and moisture conditions in Illinois are not favorable for production and dispersal of E. amylovora populations at bloom.

Although blossom infection is not a common phase of fire blight in Illinois apple orchards, fruit blight, shoot blight, canker, and root-stock blight occurs widely in the state. One possible explanation for the higher incidence of shoot blight is that rain storms are common during April and May in Illinois. We believe that injury caused by windstorms on new shoots is the main factor in initiating shoot blight, because streptomycin applications have ceased by the end of the bloom period. Similar results have been reported by previous investigators (14). Further epidemiological studies are required to determine factors affecting shoot blight in Illinois apple orchards.

Detection of Tn5393 in bacteria in orchards that have received streptomycin applications has been reported from other applegrowing areas $(12,21,22)$. This study is the first confirmation of bacterial isolates containing strA-strB paired with IS1133 in the Illinois orchards. The insertion sequence IS1133 is required for expression of strA-strB resistant genes via promoting transcription of streptomycin resistance genes $(5,12,21,22)$. The finding in this study indicates that there is a possibility of acquisition of Tn5393 streptomycin resistance into Illinois E. amylovora populations. 
Table 3. Incidence of blossom blight (caused by Erwinia amylovora) on 'Jonathan' apple trees following applications of antibiotics and biocontrol agents in Urbana, IL in 2012

\begin{tabular}{|c|c|c|c|c|}
\hline Treatment $^{w}$ & Active ingredient (rate) & $\begin{array}{c}\text { Application } \\
\text { time }^{\mathrm{x}}\end{array}$ & $\begin{array}{c}\text { Blossom } \\
\text { infection }(\%)^{y}\end{array}$ & $P$ value $^{\mathrm{z}}$ \\
\hline Control & & & $18.7 \mathrm{a}$ & \\
\hline Agrimycin 17WP & Streptomycin (100 mg/liter) & Pre/Post & $1.9 \mathrm{e}$ & 0.0485 \\
\hline Agrimycin $17 \mathrm{WP}$ & Streptomycin (100 mg/liter) & Post only & $2.5 \mathrm{e}$ & 0.0951 \\
\hline Mycoshield & Oxytetracycline ( $200 \mathrm{mg} / \mathrm{liter})$ & Pre/Post & $5.7 \mathrm{c}$ & 0.7564 \\
\hline Mycoshield + Kocide-3000 41.6DF & Oxytetracycline $(200 \mathrm{mg} / \mathrm{liter})+$ copper hydroxide $(240 \mathrm{mg} / \mathrm{liter})$ & Pre/Post & $5.6 \mathrm{c}$ & 0.8199 \\
\hline Serenade Max & Bacillus subtilis QST713 (525 mg/liter) & Pre only & $4.0 \mathrm{~d}$ & 0.3769 \\
\hline Blight Ban A506 & Pseudomonas syringae A506 (369 mg/liter) & Pre only & $4.8 \mathrm{~cd}$ & 0.9881 \\
\hline Dithane 75DF + Kocide-3000 41.6DF & Mancozeb (2,700 mg/liter) + copper hydroxide ( $240 \mathrm{mg} / \mathrm{liter})$ & Pre/Post & $5.9 \mathrm{c}$ & 0.8561 \\
\hline Kasumin $2 \mathrm{~L}$ & Kasugamycin (100 mg/liter) & Pre/Post & $2.4 \mathrm{e}$ & 0.1081 \\
\hline Kasumin $2 \mathrm{~L}$ & Kasugamycin (100 mg/liter) & Post only & $7.3 \mathrm{~b}$ & 0.8778 \\
\hline ARY 0416-06 & Kasugamycin (100 mg/liter) & Pre/Post & $1.8 \mathrm{e}$ & 0.0698 \\
\hline $\operatorname{LSD}(P=0.05)$ & $\ldots$ & $\ldots$ & 1.23 & $\ldots$ \\
\hline
\end{tabular}

${ }^{\text {w}}$ All trees were inoculated with E. amylovora isolate $2 \mathrm{~A}\left(5 \times 10^{6} \mathrm{CFU} / \mathrm{ml}\right)$ on 30 March and 3 April. Treatments included Regulaid (125 ml per 100 liters) and were applied at 1,400 liters/ha.

$\mathrm{x}$ Pre $=$ treatment was applied $24 \mathrm{~h}$ before inoculation and Post $=$ treatment was applied $24 \mathrm{~h}$ after inoculation.

${ }^{y}$ Infected blossom clusters. Infection of blossoms was assessed on 1 May 2012. The number of clusters per tree tested varied from 6 to 120 (average 70

clusters per tree). Values with a letter in common are not significantly different according to Fisher's protected least significant difference (LSD) $(P=0.05)$.

${ }^{\mathrm{z}}$ Dunnett comparison to control. Original counted cluster data were transformed $[\sqrt{ }(x+1 / 6)]$ and analyzed as a covariate in PROC MIXED.

Table 4. Severity of shoot blight (caused by Erwinia amylovora) on 'Jonathan' apple trees following application of antibiotics, biocontrol agents and prohexadione calcium (Apogee) in Urbana, IL in 2012

\begin{tabular}{|c|c|c|c|c|c|}
\hline \multirow[b]{2}{*}{ Treatment $^{\mathrm{x}}$} & \multirow[b]{2}{*}{ Active ingredient (rate) } & \multirow[b]{2}{*}{ Time $^{y}$} & \multicolumn{2}{|c|}{$\begin{array}{c}\text { Number of } \\
\text { infected shoots }\end{array}$} & \multirow[b]{2}{*}{$P$ value $^{\mathrm{z}}$} \\
\hline & & & Without & With & \\
\hline Control & & & $14.3 \mathrm{~d}$ & $15.5 \mathrm{~b}$ & 0.9285 \\
\hline Agrimycin $17 \mathrm{WP}$ & Streptomycin (100 mg/liter) & Pre/Post & $8.5 \mathrm{ef}$ & $5.5 \mathrm{f}$ & 0.6368 \\
\hline Agrimycin $17 \mathrm{WP}$ & Streptomycin (100 mg/liter) & Post only & $7.0 \mathrm{fg}$ & $3.5 \mathrm{~g}$ & 0.2216 \\
\hline Mycoshield & Oxytetracycline ( $200 \mathrm{mg} /$ liter $)$ & Pre/Post & $17.0 \mathrm{c}$ & $10.8 \mathrm{c}$ & 0.2992 \\
\hline Mycoshield + Kocide-3000 41.6DF & Oxytetracycline $(200 \mathrm{mg} / \mathrm{liter})+$ copper hydroxide $(240 \mathrm{mg} / \mathrm{liter})$ & Pre/Post & $18.5 \mathrm{c}$ & $9.8 \mathrm{cde}$ & 0.2733 \\
\hline Serenade Max & Bacillus subtilis QST713 (525 mg/liter) & Pre only & $13.9 \mathrm{~d}$ & $8.0 \mathrm{e}$ & 0.2870 \\
\hline Blight Ban A 506 & Pseudomonas syringae A506 (369 mg/liter) & Pre only & $31.3 \mathrm{a}$ & $18.5 \mathrm{a}$ & 0.1882 \\
\hline Dithane 75DF+ Kocide-3000 41.6DF & Mancozeb (2,700 mg/liter) + copper hydroxide ( $240 \mathrm{mg} / \mathrm{liter})$ & Pre/Post & $9.3 \mathrm{e}$ & $10.3 \mathrm{~cd}$ & 0.7899 \\
\hline Kasumin 2L & Kasugamycin (100 mg/liter) & Pre/Post & $23.3 \mathrm{~b}$ & $3.5 \mathrm{~g}$ & 0.0009 \\
\hline Kasumin $2 \mathrm{~L}$ & Kasugamycin (100 mg/liter) & Post only & $23.5 \mathrm{~b}$ & $8.5 \mathrm{de}$ & 0.0388 \\
\hline ARY-0416-06 & Kasugamycin (100 mg/liter) & Pre/Post & $5.5 \mathrm{~g}$ & $4.5 \mathrm{fg}$ & 0.4526 \\
\hline $\operatorname{LSD}(P=0.05)$ & $\ldots$ & $\ldots$ & 2.26 & 1.95 & $\ldots$ \\
\hline
\end{tabular}

${ }^{\mathrm{w}}$ Without $=$ no prohexadione calcium (Apogee) was applied and With $=$ of $3.363 \mathrm{~kg} / \mathrm{ha}$ of Apogee $(0.925 \mathrm{~kg} / \mathrm{ha}$ of prohexadione calcium) in two sprays $(1.68$ $\mathrm{kg} / \mathrm{ha}$ in each spray) plus Regulaid (1.25 ml/liter) were applied on 29 March (60-80\% bloom) and 12 April (petal fall), using water at 1,400 liters/ha for each application. On 22 May, 120 shoots were evaluated in each tree. Each value represents a mean of four trees and the mean of 480 shoots. Values with a letter in common are not significantly different according to Fisher's protected least significant difference (LSD) $(P=0.05)$.

${ }^{x}$ All trees were inoculated with E. amylovora isolate $2 \mathrm{~A}\left(5 \times 10^{6} \mathrm{CFU} / \mathrm{ml}\right)$ on 30 March and 3 April. Treatments included Regulaid (125 ml/100 liters) and were applied at 1,400 liters/ha.

y Application time. Pre $=$ treatment application $24 \mathrm{~h}$ before inoculation and Post $=$ treatment application $24 \mathrm{~h}$ after inoculation.

${ }^{\mathrm{z}}$ Data were transformed $[\sqrt{ }(x)]$ and analyzed in PROC MIXED. $P$ values of treatment $\times$ Apogee is shown.

Sholberg et al. (20) reported that 18 of 42 E. amylovora isolates tested in British Columbia developed colonies in the presence of $0.16 \mathrm{mM}$ copper sulfate on CYE medium. They also reported that 2 of 42 isolates developed colonies at $0.32 \mathrm{mM}$ copper sulfate on CYE. In our study, all 84 Illinois E. amylovora isolates tested were sensitive to copper sulfate at $0.16 \mathrm{mM}$. The study also showed that all four copper compounds tested prohibited cell multiplication of E. amylovora with metallic copper at $14 \mathrm{mg} / \mathrm{liter}$. Thus, the results of our study indicate that copper is still an effective compound in managing E. amylovora in early spring in Illinois.

Determining streptomycin alternatives for management of fire blight in pome fruit is essential. In 2011 and 2012 field trials, kasugamycin significantly reduced blossom infection. The results indicated that kasugamycin could be a suitable streptomycin alternative for management of fire blight disease of apple in Illinois. Further studies are needed to determine effectiveness of kasugamycin-prohexadione calcium applications for management of fire blight of apple. Oxytetracycline (Mycoshield) did not significantly reduce blossom blight infection. Similarly, biocontrol agents Serenade Max and BlightBan A506 alone did not effectively reduce blossom blight. These results are similar to the multi-year, multilocation observations reported by Sundin et al. (23). Thus, neither oxytetracycline (Mycoshield) nor biocontrol agents Serenade Max and BlightBan A506 may be considered effective streptomycin alternatives for control of fire blight in Illinois.

Results from the 2010 to 2012 surveys indicated that no streptomycin-resistant E. amylovora is currently present in Illinois. However, streptomycin-resistant strains could be introduced from other states or develop in the state. Growers should be vigilant when ordering nursery stock from states with streptomycin-resistant populations of E. amylovora, because the streptomycin resistance occurrence in New York was related to imported nursery stock (18).

\section{Acknowledgments}

This research was supported, in part, by funds from the North Central Region-Sustainable Agriculture Research and Education (Project No. GNC10139.2). We thank G. W. Sundin and G. C. McGhee from Michigan State University for their support and for sharing their research techniques and providing $E$. amylovora isolates.

\section{Literature Cited}

1. Adaskaveg, J. E., Forster, H., and Wade, M. L. 2011. Effectiveness of kasugamycin against Erwinia amylovora and its potential use for managing fire blight of pear. Plant Dis. 95:448-454. 
2. Aldwinckle, H., Breth, D., and Cox, K. 2012. Streptomycin resistant fire blight discovered in New York. N.Y. Fruit Q. 20:3-4. http://www.nyshs. org/fq.php

3. Beer, S. V. 1997. Fire blight. Pages 61-63 in: Compendium of Apple and Pear Diseases. A. L. Jones and H. S. Aldwinckle, eds. American Phytopathological Society, St. Paul, MN.

4. Billing, E., Crosse, J. E., and Garrett, C. U. E. 1960. Laboratory diagnosis of fire blight and bacterial blossom blight of pear. Plant Pathol. 9:19-25.

5. Chiou, C. S., and Jones, A. L. 1993. Nucleotide sequence analysis of a transposon (Tn5393) carrying streptomycin resistance genes in Erwinia amylovora and other gram negative bacteria. J. Bacteriol. 175:732-740.

6. Cooley, D. R., Autio, W. R., Clements, J. M., Cowgill, W. P., and Spitko R. 2008. Annual fire blight management programs for apples. University of Massachusetts Extension. http://www.umass.edu/fruitadvisor/factsheets/F-133.pdf

7. Copping, L. G., and Duke, S. O. 2007. Natural products that have been used commercially as crop protection agents. Pest Manage. Sci. 63:524-554.

8. Kado, C. I. 2010. Rapid necrotizing diseases. Pages 79-84 in: Plant Bacteriology. American Phytopathological Society, St. Paul, MN.

9. Kleitman, F., Manulis, S., Kritzman, G., Oppenheim, D., Zilberstaine, M., and Shtienber, D. 2004. Use of a diagnostic medium for in situ determination of the response of Erwinia amylovora strains to bactericides. Phytoparastica 32:127-131.

10. Lane, D. J. 1991. 16S/23S rRNA sequencing. Pages 115-175 in: Nucleic Acid Techniques in Bacterial Systematics. E. Stackebrandt and M. Goodfellow, eds. J. Wiley and Sons Ltd., Chichester, UK.

11. Loper, J. E., Henkels, M. D., Roberts, R. G., Grove, G. G., Willet, T. J., and Smith, T. J. 1991. Evaluation of streptomycin, oxytetracycline and copper resistance of Erwinia amylovora isolated from pear orchards in Washington State. Plant Dis. 75:287-290.

12. McGhee, G., Guasco, J., Bellomo, L., Blumer-Schuette, S., Shane, W., Irish-Brown, A., and Sundin, G. W. 2011. Genetic analysis of streptomycinresistant (SmR) strains of Erwinia amylovora suggests that dissemination of two genotypes is responsible for the current distribution of SmR E. amylovora in Michigan. Phytopathology 101:182-191.

13. McGhee, G., and Sundin, G. W. 2011. Evaluation of kasugamycin for fire blight management, effect on nontarget bacteria, and assessment of kasugamycin resistance potential in Erwinia amylovora. Phytopathology 101:192-204.

14. McManus, P. S., and Jones, A. L. 1994. Role of wind-driven rain, aerosols, and contaminated budwood in incidence and spatial pattern of fire blight in an apple nursery. Plant Dis. 78:1059-1066.

15. McManus, P. S., and Jones, A. L. 1995. Detection of Erwinia amylovora by nested PCR and PCR-dot-blot and reverse-blot hybridizations. Phytopathology 85:618-623.

16. Miller, T. D., and Schroth, M. N. 1972. Monitoring the epiphytic population of Erwinia amylovora on pear with selective medium. Phytopathology 62:1175-82.

17. Norelli, J. L., Farrell, R. E., Bassett, C. L., Baldo, A. M., Lalli, D. A., Aldwinckle, H. S., and Wisniewski, M. E. 2009. Rapid transcriptional response of apple to fire blight disease revealed by cDNA suppression and subtractive hybridization analysis. Tree Genet. Genomes 5:27-40.

18. Russo, N. L., Burr, T. J., Breth, D. I., and Aldwinckle, H. S. 2008. Isolation of streptomycin resistant isolates of Erwinia amylovora in New York. Plant Dis. 92:714-718.

19. Saxton, A. M. 1998. A macro for converting mean separation output to letter groupings in Proc Mixed. Pages 43-1246 in: Proc. 23rd SAS Users Group Int. SAS Institute, Cary, NC.

20. Sholberg, P. L., Bedford, K. E., Haag, P., and Randall, P. 2001. Survey of Erwinia amylovora isolates from British Columbia for resistance to bactericides and virulence on apple. Can. J. Plant Pathol. 23:60-67.

21. Sundin, G. W., and Bender, C. L. 1995. Expression of the strA-strB streptomycin resistance genes in Pseudomonas syringae and Xanthamonas campestris and characterization of IS6100 in X. campestris. Appl. Environ. Microbiol. 61:2891-2897.

22. Sundin, G. W., and Bender, C. L. 1996. Dissemination of the strA-strB streptomycin resistance genes among commensal and pathogenic bacteria from humans, animals, and plants. Mol. Ecol. 5:133-143.

23. Sundin, G. W., Werner, N. A., Yoder, K. S., and Aldwinckle, H. S. 2009. Field evaluation of biological control of fire blight in the eastern United States. Plant Dis. 93:386-394. 